DOE/ER/54432

"PLASMA COLLOQUIUM TRAVEL GRANT PROGRAM"

FINAL REPORT

SEPTEMBER 14, 1998

\author{
Richard D. Hazeltine, Director \\ Institute for Fusion Studies \\ The University of Texas at Austin
}

Austin, Texas 78712-1068

PREPARED FOR THE U.S. DEPARTMENT OF ENERGY

UNDER GRANT NUMBER

DE-FG03-97ER-54432 


\section{DISCLAIMER}

This report was prepared as an account of work sponsored by an agency of the United States Government. Neither the United States Government nor any agency thereof, nor any of their employees, make any warranty, express or implied, or assumes any legal liability or responsibility for the accuracy, completeness, or usefulness of any information, apparatus, product, or process disciosed, or represents that its use would not infringe privately owned rights. Reference herein to any specific commercial product, process, or service by trade name, trademark, manufacturer, or otherwise does not necessarily constitute or imply its endorsement, recommendation, or favoring by the United States Government or any agency thereof. The views and opinions of authors expressed herein do not necessarily state or reflect those of the United States Government or any agency thereof. 


\section{DISCLAIMER}

Portions of this document may be illegible in electronic image products. Images are produced from the best available original document. 


\title{
Plasma Colloquium Travel Grant Program
}

\author{
Dr. Michael Zarnstorff, Princeton Plasma Physics Laboratory \\ Lecture Title: "Suppression of turbulence in plasmas: an experimentalist's view"
}

These lecturers have been presenting plasma colloquia at US universities and colleges in order to acquaint faculty, researchers and student with the research accomplishments in plasma physics. The universities and colleges visited or to be visited by the lecturers, where 19 colloquia have been scheduled, are as follows:

\author{
University of Alabama, Huntsville \\ University of North Carolina, Chapel Hill \\ University of Central Arkansas \\ SUNY, Stony Brook \\ California State University, Fresno \\ Clemson University \\ Rice University \\ Millersville University \\ University of Connecticut
}

\author{
Kent State \\ New Mexico State \\ Sonoma State University \\ Stanford University \\ Texas Tech University \\ University of Indiana \\ SUNY, Buffalo \\ Cal Tech \\ Dartmouth University
}

The distinguished lecturers were announced in the November issue of the APS News. In addition, letters were mailed to the Department Chairpersons of Physics Departmerts and an announcement was placed on a web page that could be accessed through the APS website (www.aps.org) on the DPP homepage. Comments on this program by two of the lecturers are provided on pages 4 and 5 . The reaction has been positive and the lectures were well received. At universities with no plasma program there may have been difficulty in attracting students to the lectures, but the lack of student awareness and the lack of knowledge of the accomplishments in plasma physics are precisely why these lectureships were suggested.

\section{Budget Request for FY 1999}

The budget request for FY 1999 is as follows:
$\$ 11,000$ Travel expenses
1,000 Publicity expenses
4,100 G\&A (offsite rate@34\%)
$\$ 16,100$ Total 
To: Barbara Shrauner and Richard Hazeltine

From: Bill Kruer

Re: Plasma Lecture Program

'Ihis was a wonderful ldea. Many thanks to those who thought of it and made it possible. I was invited to give 10 seminars but only accepted 7 . Five were funded by the DOE grant administered by the University of Texas, and two were funded by LINL. I made a polnt of spending the day and very much enjoyed interacting with the faculty and students. In one case, I also taught part of two classes, providing the students with some plasma concepts as background for the seminar. In all cases, I was treated very warmly and felt appreciated. I think that there is clearly a hunger for morc communication between different sub fieids of physics and that such interactions are mutually beneficial. Hopefully the grant will be continued next year and will cnable a new set of plasma seminars. Even if or when the grant is no longer in place, 1 would encourage the DPY to still choose some lecturers each year and advertise them as available provided the interested department funds the travel. I also rccommend that the laboratories and the university programs provide some support for the travel expenses. These programs surely benefit from making connections with and getting feedback from the larger physics community.

PS My seminars were given at

Univ. of North Carolina, Chapel Hill

Univ. of North Arkansas

SUNY, Stony Brook

Callfornia State Üniversity, Fresno

Univ. of Alabama, Huntsville

Clemson University

SUNY, Buffalo (to be given April 14)

Contact people at each institution have been idientified to Richard. It would no doubt be especially valuable to get their feedback. 


\section{U.S. DEPARTMENT OF ENERGY}

FIELD WORK PROPOSAL 1. CONIRACTOR NO.
1075

4. WORK PROPOSAL TITLE

Plasma Colloquium Travel Grant Program

6. WORK PROPOSAL TERM

Begin: 10/1/98 End: 9/30/99

2. REVISION. NO.

0

5. BUDGET AND REPORTING CODE

AT5010702

7. IS THIS WORK PACKAGE INCLUDED

IN THE INSTITUTIONAL PLAN? No

8. CONTRACTOR WORK PROPOSAL MANAGER (Name, Telephone \#):

Professor Nathaniel J. Fisch (609-243-2643)

9. HEADQUARTERS ORGANIZATION:

Energy Research

10. FIELD OFFICE:

Chicago Operations Office

11. CONTRACTOR NAME:

Princeton University

Princeton Plasma Physics Laboratory
12. DOE HQ ORGANIZATION CODE:

ER

13. DOE OPS OFFICE ORGANIZATION CODE: $\mathrm{CH}$

14. CONTRACTOR CODE:

15

WORK PROPOSAL DESCRPPTION:

The Division of Plasma Physics (DPP) of the American Physics Society (APS) proposes that the Office of Fusion Energy Sciences continue the Plasma Colloquium Travel Grant Program that was established in 1997.

At the March 1998 meeting of the DPP Executive Committee, the Committee recognized the success of the first year of the Travel Grant Program and enthusiastically recommended that the program be continued. The program has indeed attracted distinguished lecturers, who have done an excellent job of conveying the excitement of research in plasmas at university and college campuses throughout the country. Accordingly, we requested funding for a continuation of the program for a period of one-year beginning October 1, 1998. The funds will be used for travel and lodging of the distinguished lecturers. A small portion of the funds will be used to publicize the program at U.S. universities and colleges.

For FY 1999, the Travel Grant Program will be administered by the Princeton Plasma Physics Laboratory. The task manager will be Professor Nathaniel J. Fisch, Professor of Astrophysical Sciences at Princeton University and Chair of the APS Division of Plasma Physics. 


\section{Plasma Colloquium Travel Grant Program}

\section{Purpose}

The purpose of the Travel Grant Program is to increase the awareness of plasma research. The new results and techniques of plasma research in fusion plasmas, plasma processing, space plasmas, basic plasma science, etc, have broad applicability throughout science. The benefits of these results are limited by the relatively low awareness and appreciation of plasma research in the larger scientific community. Whereas spontaneous interactions between plasma scientists and other scientists are useful, a focused effort in education and outreach to other scientists is efficient and is needed. The academic scientific community is the initial focus of this effort, since that permits access to a broad cross-section of scientists and future scientists including undergraduates, graduate students, faculty, and research staff.

Under the Travel Grant Program, distinguished lecturers, who are selected by the Colloquium Travel Committee of the APS Division of Plasma Physics, are available for talks at US colleges and universities. Preference is given to invitations from colleges and universities that do not have substantial programs in plasma physics. The lecturers' travel expenses are support by this grant.

\section{Plasma Colloquium Travel Grant Program for 1997-98}

The Plasma Colloquium Travel Grant Program in its first year is a success with even more colloquia presented than expected. The Office of Fusion Energy Sciences awarded $\$ 15,100$ to the Division of Plasma Physics of the American Physical Society for the program for a one-year period beginning September 15, 1997. The grant is being administered through the University of Texas with Dr. Richard Hazeltine serving as Principal Investigator. This Travel Grant Program was approved at the November, 1996 APS Division of Plasma Physics Executive Committee meeting held in Denver. The Lecturers for 1997-98, their affiliation and titles of their lectures are listed below:

Dr. William Kruer, Lawrence Livermore National Laboratory

Lecture Title: "The interaction of plasma with intense lasers and tine quest for fusion"

Professor Thomas ONeil, Department of Physics, University of California at San Diego Lecture Title: "Equilibria and dynamics of pure electron and ion plasmas"

Professor Stewart Prager, Department of Physics, University of Wisconsin Lecture Title: "Dynamo and chaotic magnetic fields in plasmas"

Professor Francis Chen, UCLA

Lecture Title: "Computer chips to potato chips: the challenge of plasma processing" 